\title{
The Hidden Benefits of Being an Involved Father ${ }^{1}$
}

\section{Garret D. Evans and Kate Fogarty ${ }^{2}$ \\ Overview}

Most people can agree that having an involved father has obvious benefits to children. Many of us have read newspapers or seen TV programs that talk about the clear benefits of fathers being involved in raising a child by providing love, support, and comfort. We can probably also agree that fathers are important because they help to teach children values and lessons in solving the problems they may face. Fathers also serve as role models in their childern's lives that affect how well they relate to peers and adults outside the home.

Before you think- "wait a minute, what about mothers?"- tell yourself that it's not a question of who is more important: mothers or fathers. The point is that having both parents involved in rearing their child has some obvious, and some maybe not-so-obvious, benefits for the child, the family, and for fathers themselves.

\section{Benefits for Children}

When we talk about the benefits of being an involved father, we most often focus on the benefits that children receive from such a relationship. It makes a lot of sense to focus on children. After all, being an involved father means being actively involved in nearly every aspect of your child's life (Marsiglio et al., 2000), from direct interaction (play) and responsibility for childcare to making oneself available to his child (Palkovitz, 2002).

Also, the benefits of having a father involved in raising his children are pretty clear. Researchers have been studying this issue for decades. For instance, did you know that ...?

- babies as young as three months old can tell the difference between their mother and father. They can tell by the way each speaks to them, holds them, and by their different smells.

- research has shown that children whose fathers are involved in rearing them score higher on cognitive tests (they seem smarter) than those with relatively uninvolved fathers.

1. This document is FCS2141, one of a series of the Family, Youth, and Community Sciences Department, Florida Cooperative Extension Service, Institute of Food and Agricultural Sciences, University of Florida. Published: December 1999. Revised: July 2005. Please visit the EDIS Web site at http://edis.ifas.ufl.edu

2. Garret D. Evans, Psy.D., former assistant professor in Clinical Psychology, and Kate Fogarty, Ph.D., assistant professor, Youth Development, both of the Department of Family, Youth and Community Sciences, Florida Cooperative Extension Service, Institute of Food and Agricultural Sciences, University of Florida, Gainesville FL 32611.

The Institute of Food and Agricultural Sciences (IFAS) is an Equal Opportunity Institution authorized to provide research, educational information and other services only to individuals and institutions that function with non-discrimination with respect to race, creed, color, religion, age, disability, sex, sexual orientation, marital status, national origin, political opinions or affiliations. U.S. Department of Agriculture, Cooperative Extension Service, University of Florida, IFAS, Florida A. \& M. University Cooperative Extension Program, and Boards of County Commissioners Cooperating. Larry Arrington, Dean 
- improved cognitive abilities are associated with higher educational achievement. In fact, fathers who are involved in their children's schools and academic achievement, regardless of their own educational level, are increasing the chances their child will graduate from high school, perhaps go to vocational school, or even to college.

- a father's involvement in children's school activities protects at-risk children from failing or dropping out

- research shows that fathers who are more involved with their children tend to raise children who experience more success in their career. Career success can lead to greater income and greater financial stability.

- involved fathering is related to lower rates of teen violence, delinquency, and other problems with the law.

- faher involvement is associated with positive child characteristics such as empathy, self-esteem, self-control, psychological well-being, social competence, and life skills.

- children who grow up in homes with involved fathers are more likely to take an active and positive role in raising their own families. For example, fathers who recall a secure, loving relationship with both parents were more involved in the lives of their infants and more supportive to their wives. It is thought that having an involved father provides a role model for positive parenting, healthy caregiving, and a commitment to the family.

\section{Benefits for Children with Non-resident Fathers}

Along these same lines, the involvement of nonresidential fathers (fathers who don't live in the same home as their child) seems to be particularly important.

Did you know that children who grow up with non-resident fathers that stay very involved in their life...?
- tend to get higher grades than those without involved fathers.

- seem to have better social skills. They can make friends more easily and handle difficult social situations better.

- tend to have fewer behavioral problems. In fact, even when not living with their children and their children's mother, fathers who were actively involved with their children kept them from getting involved in problem behaviors as teens

- have fewer mental health problems as adults (especially true for daughters).

\section{Benefits for the Family}

The family benefits from having an involved father. These benefits come from having loving and nurturing relationships among family members, not only between parents and children, but between a spouse, partner, or relative. Being involved in caring, not only for the child, but for the family can bring greater harmony and fewer arguments. The family tends to enjoy their time together more.

Did you know that involved fathering is related to... ?

- better communication between fathers and family members;

- a greater sense of commitment to the family;

- less troubling conflict with teenage children.

\section{Benefits for Fathers}

Finally, being an involved father brings benefits to dads themselves. When fathers build strong relationships with their children and others in the family, they receive support and caring in return. Research has shown that healthy family relationships provide the strongest and most important support network a person can have, whether that person is a child or an adult.

Being involved in their family members lives helps fathers to... 
- enjoy a secure attachment relationship with their children.

- cope well with stressful situations and everyday hassles.

- feel as if they can depend on others more.

- feel more comfortable in their occupation and feel that they can do their job well.

- feel confident they have a lot to offer others in terms of their job skills, parenting skills, and social relationships.

The benefits listed above are really only a few of the major research findings from studies of families with involved and uninvolved fathers. Many of the benefits may seem obvious, but perhaps not all of them. If you look at your own involvement in your family, you might discover that you have been enjoying some of the benefits listed above without really noticing it. Sometimes being an involved parent takes hard work and setting priorities. Don't forget to stop and look around once in awhile to see all that you are getting in return.

\section{References}

Almeida, D. \& Galambos, N. (1991). Examining father involvement and the quality of father-adolescent relations. Journal of Research on Adolescence, 1, 155-172.

Bernadett-Shapiro, S., Ehrensaft, D., \& Shapiro, S. (1996). Father participation in childcare and the development of empathy in sons: An empirical study. Family Therapy, 23, 77-93.

Blum, R.W., Beuhring, T., Shew, M.L., Bearinger, L.H., Sieving, R.E., \& Resnick, M.D. (2000). The effects of race/ethnicity, income, and family structure on adolescent risk behaviors. American Journal of Public Health, 90, 1879-1884.

Flouri, E., \& Buchanan, A. (2002). The role of father involvement in childrens later mental health. Journal of Adolescence, 26, 63-78.

Gadsden, V., \& Aisha, R. (2003). Fathers role in childrens academic achievement and early literacy.
ERIC Digest Document ED482051. Champaign, IL: ERIC Clearinghouse on Elementary \& Early Childhood Education.

Hossain, Z., \& Roopnarine J. (1994). African-American fathers' involvement with infants: Relationship to their functioning, style, support, education, and income. Infant Behavior \& Development 17, 175-184.

Jain, A., Belsky, J., \& Crnic, K. (1996). Beyond fathering behaviors: Types of dads. Journal of Family Psychology, 10, 431-442.

King, V. (1994). Nonresident father involvement and child well-being: Can dads make a difference? Journal of Family Issues, 15, 78-96.

Marsiglio, W., Day, R.D., \& Lamb, M.E. (2000). Exploring fatherhood diversity: Implications for conceptualizing father involvement. Marriage and Family Review, 29, 269-293.

McBride, B., Schoppe-Sullivan, S.J., \& Ho, M.H. (2005). The mediating role of fathers school involvement on student achievement. Applied Developmental Psychology, 26, 201-216.

Palkovitz, R. (2002). Involved fathering and child development: Advancing our understanding of good fathering. In C.S. Tamis-LeMonda \& N. Cabrera (Eds.), Handbook of father involvement: Multidisciplinary perspectives. Mahwah, NJ: Lawrence Erlbaum (pp. 119-140).

Parke, R.D., McDowell, D.J., Kim, M., Killian, C., Dennis, J., Flyr, M.L., \& Wild, M.N. (2002). Fathers contributions to childrens peer relationships. In C.S. Tamis-LeMonda \& N. Cabrera (Eds.), Handbook of father involvement: Multidisciplinary perspectives. Mahwah, NJ: Lawrence Erlbaum (pp. 141-167).

William, E., N. Radin, \& Allegro, T. (1992). Sex role attitudes of adolescents reared primarily by their fathers: An 11-year follow-up. Merrill Palmer Quarterly, 38, 457-476. 